\title{
Update on Therapeutic Approaches for Rheumatoid Arthritis
}

\author{
Eugénia Nogueira ${ }^{\mathrm{a}}$, Andreia Gomes ${ }^{\mathrm{a}}$, Ana Preto a and Artur Cavaco-Paulo, \\ ${ }^{a}$ CEB - Centre of Biological Engineering, University of Minho, Campus of Gualtar, Braga, Portugal \\ ${ }^{b}$ CBMA (Centre of Molecular and Environmental Biology) Department of Biology, University of Minho, Campus of Gualtar, Braga, \\ Portugal
}

ARTICLE HISTORY

Received: November 29, 2015 Revised: April 26, 2016 Accepted: May 04, 2016

DOI: http://dx.doi.org/10.2174/09 2986732366616031612506

\begin{abstract}
Rheumatoid arthritis is a common chronic inflammatory and destructive arthropathy that consumes considerable personal, social and economic costs. It consists of a syndrome of pain, stiffness and symmetrical inflammation of the synovial membrane (synovitis) of freely moveable joints such as the knee (diarthrodial joints). Although the etiology of rheumatoid arthritis is unclear, the disease is characterized by inflammation of the synovial lining of diarthrodial joints, high synovial proliferation and an influx of inflammatory cells, macrophages and lymphocytes through angiogenic blood vessels. Disease-modifying antirheumatic drugs slow disease progression and can induce disease remission in some patients. Methotrexate is the first line therapy, but if patients become intolerant to this drug, biologic agents should be used. The development of biological substances for the treatment of rheumatic conditions has been accompanied by ongoing health economic discussions regarding the implementation of these highly effective, but accordingly, highly priced drugs are the standard treatment guidelines of rheumatic diseases. In this way, more efficient strategies have to be identified. Despite numerous reviews in rheumatoid arthritis in the last years, this area is in constant development and updates are an urgent need to incorporate new advances in rheumatoid arthritis research. This review highlights the immunopathogenesis rationale for the current therapeutic strategies in rheumatoid arthritis.
\end{abstract}

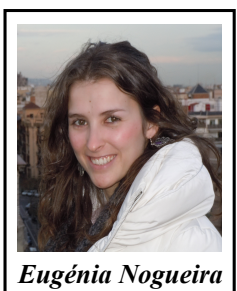

Keywords: Animal models, DMARDs, Immunopathogenesis, Rheumatoid arthritis, Therapy.

\section{INTRODUCTION}

Rheumatoid arthritis (RA) is the most common form of chronic inflammatory arthritis, characterized by inflammation of the joints, resulting in synovial hyperplasia by infiltration of activated immune cells leading to further cartilage and bone destruction [1]. In 1500 BC, Ebers Papyruralies described a condition similar to RA. Several reports have suggested over time that Egyptian mummies were found to have deformities similar to arthritis, however only in 1800 this condition was named RA by Garrod, replacing the old terms arthritis deformans and rheumatic gout [2].

\footnotetext{
* Address correspondence to this author at the CEB - Centre of Biological Engineering, University of Minho, Campus of Gualtar, 4710-057 Braga, Portugal; Tel/Fax: 00351253604409, 0035125 3604429; E-mail: artur@deb.uminho.pt
}

RA occurs worldwide although the estimated prevalence ranges from around $1 \%$ of the adult population in northern Europe and USA to around $0.5 \%$ in other geographic areas. This disease is clearly commonest in women than in men with a ratio of approximately 3:1 [3]. RA can develop in persons of any age, with a typical onset age of 55 years [4]. Mortality rates in RA are higher than in the general population (ranges from 1.28 to 2.98 ) [5]. Life expectancy is shortened by up to 3 to 5 years, especially in patients that develop treatmentrelated adverse effects including infections, tumors and gastrointestinal toxicity from drugs used in RA therapy $[4,6]$. Furthermore, it is known that patients with RA are at increased risk for acute cardiovascular events, compared with the rest of the population [7]. In this way, the commonest cause of death in RA is cardiovascular diseases, accounting for more than $50 \%$ of the mortality [1]. 


\section{Genetic Factors and Environmental Pressure}

As many other diseases, RA is a combination of genetic and environmental factors that when present, increase the susceptibility to develop clinical manifestations [2]. Several loci contribute to the genetic risk for RA, with the human leukocyte antigen (HLA) locus being the most significant, and accounting for $30 \%$ to $50 \%$ of overall genetic susceptibility to RA [8]. HLA molecules are essential for antigen presentation in the immune response. Although the association between HLA and RA is not fully understood, it appears that antigen presentation and the type of immune activation that leads to (auto)antibody formation are important in RA [9]. Other locus with strong association are described in Table $\mathbf{1}$, highlighting a polymorphism in the protein tyrosine phosphatase nonreceptor 22 (PTPN22) gene, which encodes the protein tyrosine phosphatase [8]. Recent genome-wide association studies (GWAS) meta-analysis discovered novel RA risk loci with significant at a genome-wide level of significance, accounting for $101[10,11]$. However, these risk loci do not fully explain the genetic contribution to disease susceptibility, and common genetic variants do not have equal causative effects $[12,13]$.

Several environmental factors have been associated in the development of RA, however not all are consensual. It is believed that early life factors, such as higher birth weight or maternal smoking, may be important in developing the risk of RA. Tobacco smoking is the environmental factor remarkably most associated with a higher risk of RA [3]. A study revealed that smoking history of more than 40 pack-years increases 2-fold the risk of RA (compared to nonsmokers), persisting even after smoking cessation [15]. However, this higher risk of RA is just presented in patients with seropositive RA (rheumatoid factor, $\mathrm{RF}$, positive) and, especially, patients with positive anti-citrullinated peptide/ protein antibodies (ACPA) [3]. Other bronchial stressors such as silica are also defined as risk factors for severe RA. Furthermore, infectious agents, such as Porphyromonas gingivalis associated with periodontal disease, are also linked to RA as environmental factors [15].

Table 1. Genetic susceptibility to RA $[8,14]$.

\begin{tabular}{|c|c|c|}
\hline Gene/locus & Odds ratio & Function Relevant to Pathogenesis \\
\hline$H L A-D R B 1$ SE alleles & $\begin{array}{l}\text { Single SE } \sim 3 \text { to } \\
4.5 ; \text { double SE } \\
\sim 7 \text { to } \sim 13\end{array}$ & $\begin{array}{l}\text { HLA DRB1 allele involved in MHC molecule-based antigen presentation and accountable } \\
\text { for self-peptide selection and T-cell repertoire }\end{array}$ \\
\hline$P T P N 22$ Arg620 $\rightarrow$ Trp & $\sim 1.6$ & $\begin{array}{l}\text { Lymphocyte-specific nonreceptor tyrosine phosphatase imlivated in regulation of } \\
\text { activation threshold of lymphocytes }\end{array}$ \\
\hline STAT4 & $\sim 1.3$ & $\begin{array}{c}\text { Transducer of cytokine signals that control proliferation, survival, and differentiation of } \\
\text { lymphocytes }\end{array}$ \\
\hline TNFAIP3 & $\sim 1.2$ & Signaling protein and negative regulator of TNF- $\alpha$-induced NF-kB activation \\
\hline TRAF1/C5 & $\sim 1.3$ & Regulator of TNF- $\alpha$-receptor superfamily signaling (e.g., to NF-אB and JNK) \\
\hline
\end{tabular}

SE: shared epitope; STAT: signal transducer and activator of transcription; TNFAIP3: tumor necrosis factor alpha induced protein 3; TRAF1/C5: tumor necrosis factor-associated factor 1 and complement component C5; MHC: major histocompatability complex; TNF: tumor-necrosis factor; NF-кB: factor nuclear kappa B; JNK: Janus N-terminal kinase

\section{Classification Criteria}

The classification criteria of RA proposed by the American College of Rheumatology (ACR) in 1987 differentiated established RA from other rheumatic disorders [16], but it is not precise for early disease stages. Indeed, the classification criteria were based on patients in whom the average disease duration was 7 years and were consequently highly specific for established RA [17]. Four of the seven next criteria must be present, and criteria 1-4 must have been present for at least 6 weeks: morning stiffness ( $\geq 1 \mathrm{hr}$ ); arthritis of three or more joints areas; arthritis of hand joints $(>1$ swollen joint); symmetric arthritis; rheumatoid nodule; serum RF; radiographic changes (erosions).

Actually, it is known that there is a period of development of RA that is characterized by abnormalities of autoantibodies and other 
biomarkers in the absence of clinically apparent inflammatory arthritis that characterizes RA [18]. The first RA-associated antibody, RF, was discovered in 1940, and it was posteriorly found to be directed to the crystallizable fragment $(\mathrm{Fc})$ region of imunoglobulina (Ig)G. More recently, it has been shown that the autoantibodies present in RA are antibodies directed against proteins containing citrulline epitopes. These antibodies are called ACPA and can recognise the non-classical amino acid citrulline, present on a protein sequence. Citrulline is produced by a post-translational modification of arginine mediated by an enzymatic process. This reaction occurs during a variety of biological processes, including inflammation [9]. In fact, there are commercially available anti-cyclic Citrullinated Peptide (CCP) ELISA assays, based on artificial $\mathrm{CCP}$, of which several generations exist (e.g.., CCP2, CCP3) [18].

New criteria for the classification/ diagnosis of RA were therefore proposed in 2010 by experts from both ACR and European League Against Rheumatism (EULAR) [19]. The most common clinical manifestations of RA are gradual onset of polyarthralgia with symmetrical, intermittent and migratory joint involvement, especially in the hands and feet. It is important to note that, due to its clinical importance, feet involvement was included in the ACR/EULAR 2010 classification, despite the fact that their involvement was not part of some of the activity index. Symmetrical inflammation of small and large articulations accompanied by morning stiffness is also a common symptom of RA [2].

The new criteria consider a probabilistic method to RA diagnosis and are particularly useful before the erosions that are typical when RA is detected (Fig. 1). They include four scored areas: symptom duration $(<$ or $>6$ weeks), number and site of involved joints, biomarkers of inflammation (acutephase response), and biomarkers of specific autoimmunity (RF and ACPA).

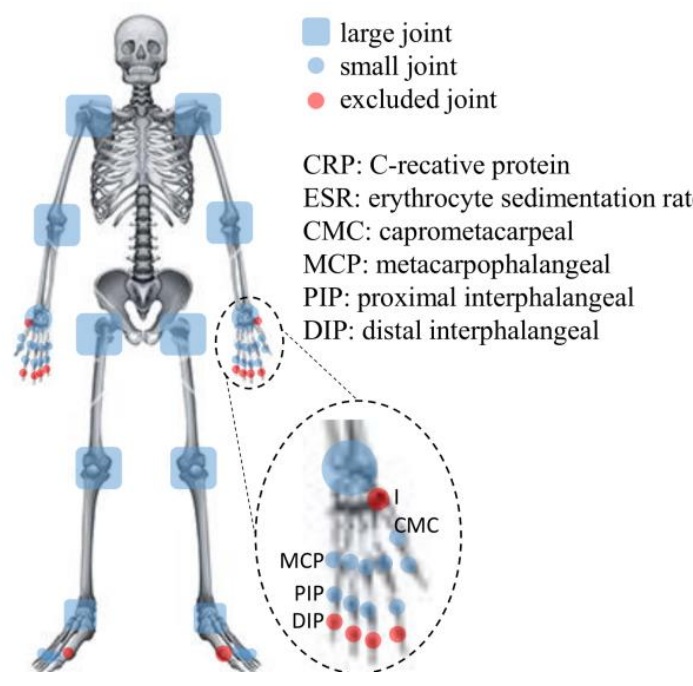

\begin{tabular}{|c|c|c|}
\hline Domain & Category & Point score \\
\hline \multirow{5}{*}{$\begin{array}{l}\text { A. Joint involvement }(0-5 \\
\text { points) }\end{array}$} & 1 large joint & 0 \\
\hline & 2-10 large joints & 1 \\
\hline & $1-3$ small joints (large joints not counted) & 2 \\
\hline & 4-10 small joints (large joints not counted) & 3 \\
\hline & $\begin{array}{l}>10 \text { joints including at least one small } \\
\text { joint }\end{array}$ & 5 \\
\hline \multirow{3}{*}{$\begin{array}{l}\text { B. Serology (at least one } \\
\text { test needed for } \\
\text { classification) }\end{array}$} & Negative RF and negative ACPA & 0 \\
\hline & Low positive RF or low positive ACPA & 2 \\
\hline & High positive RF or high positive ACPA & 3 \\
\hline \multirow{2}{*}{$\begin{array}{l}\text { C. Acute-phase reactants } \\
\text { (at least one test needed } \\
\text { for classification) }\end{array}$} & Normal CRP and normal ESR & 0 \\
\hline & Abnormal CRP or abnormal ESR & 1 \\
\hline \multirow[t]{2}{*}{ D. Duration of symptoms } & $<6$ weeks & 0 \\
\hline & $\geq 6$ weeks & 1 \\
\hline
\end{tabular}

Fig. (1). Classification criteria of RA on earlier stages.

Only patients with at least 6 in 10 points, may be classified as having RA. Obviously, the criteria do not apply if patients already have joint erosions that are visible on standard X-rays [17]. In addition to identifying individuals at high risk for chronic disease activity and erosive damage, these criteria would also be used as a base for selecting patients who require targeted treatment early in disease progress [20].
It is possible to define three phases in RA pathogenesis. In the first phase, autoimmunity develops in healthy but genetic-susceptible individuals, wh0 have not experienced any clinical manifestation. The second phase refers to the time immediately before to or the clinical start for diagnosis of RA. This stage has been difficult to study in man, despite several efforts made for the detection of first signs and symptoms of disease. In 
the third phase, inflammation is converted into a chronic and destructive process. At this stage the patients meet the classification criteria of RA, and they become the target of therapeutic approaches [21].

\section{Immunopathogenesis}

Being an autoimmune disease, RA patients have a problem in distinguishing between self and foreign molecules. Humoral and cellular immune responses to autoantigens, like the production of
RFs, occur in RA [1]. Although the cause of RA remains unclear, it is known that the immune and inflammatory systems are closely related to the destruction of cartilage and bone [22]. Indeed, the complex interaction of immune modulators (cytokines and effector cells) leads to joint damage that begins at the synovial membrane and affects most RA structures (Fig. 2). The influx and/or local activation of mononuclear cells (including macrophages and T, B, plasma, dendritic and mast cells) and the formation of new blood vessels are characteristic of synovitis [23].

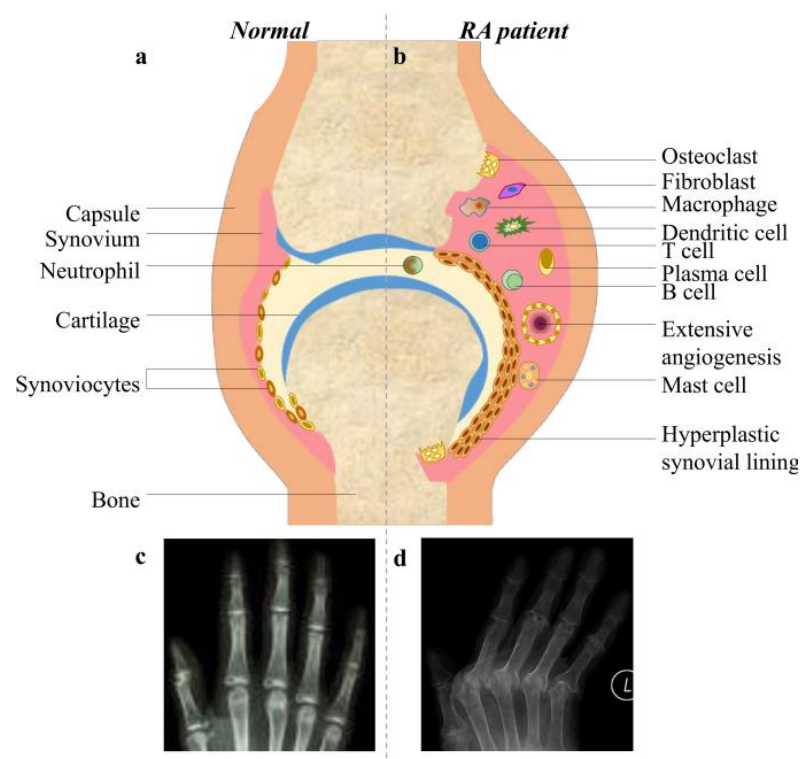

Fig. (2). Schematic view of a (a) normal joint and (b) a joint affected by RA. The 'radiographic joint space' of metacarpophalangeal joints in (c) a normal hand and (d) from a patient with established RA (Adapted from Nogueira et al., 2016 [33]).

\section{T Cells}

CD4+ helper $\mathrm{T}(\mathrm{Th})$ cells make a crucial contribution to the development of inflammatory arthritis, where two T-cell subsets have been well characterized. $\mathrm{T}$ cells undergo polarization into either Th1 or Th2 cells, which is mutually exclusive. Th1 cells have pro-inflammatory potential and promote certain humoral responses, whereas Th2 cells exert anti-inflammatory effects [22]. RA is clearly characterized by a change in the direction of the pro-inflammatory Th1 phenotype, with overproduction of interferon (IFN) $\gamma$ and unsuited production of Th2 cytokines like interleukin (IL)-4 and IL-13.

The model attributing a key role to a Th1/Th2 imbalance in RA was clarified by the identification of Th17 and T-regulatory (Treg) lymphocyte subsets [24]. Th17 cells produce the proinflammatory cytokine IL-17, which acts on several cell types found in rheumatoid joints: monocytes, macrophages, fibroblasts, osteoclasts and chondrocytes. Furthermore, this cytokine also induces a wide range of effector molecules implicated in joint damage [8]. The immune response needs to be controlled to avoid chronic inflammation. For this purpose, Treg cells, known to have suppressor activity, are pivotal in the maintenance of selftolerance [25]. Although Treg cells can regulate any $\mathrm{Th}$ subset, special attention has been given to the Th17/Treg balance [26]. 
Th22 subset is a more recently identified Th subset, which is characterized by secretion of IL-22 but not IL-17 or IFN- $\gamma$ [27]. IL-22, a member of IL-10 cytokine family, has been believed as an important player in regulating inflammatory responses associated with many inflammatory diseases [28]. It was demonstrated that the number of Th22 cells significantly increased in the peripheral blood of patients with RA compared with healthy controls $[28,29]$. However, recent results indicate that Th22 cells are less potent in inducing synovial inflammation compared to Th17 cells [30].

Although its role is not fully understood, Th9 are also overexpressed in RA synovial tissue [31]. This cell subset, characterized by the production of IL-9, is increased in RA and is specifically activated by citrullinated peptides [32].

\section{B Cells}

B cells play several key roles in the pathogenesis of RA. Their primary function is the production of autoantibodies, RF and ACPA, resulting in a large immunecomplex. Through complement and Fc-receptor activation, this structure can stimulate the production of proinflammatory cytokines, such as TNF- $\alpha[1,23]$. Furthermore, B cells with specificity for selfimmunoglobulin can bind and internalize immunoglobulin- antigen complexes and enhance antigen-presenting function by generating a wider range of peptides [34]. In this way, besides the production of autoantibodies and pro-inflammatory cytokines, $\mathrm{B}$ cells can also present antigens to $\mathrm{T}$ cells and supply costimulatory signals which are crucial for $\mathrm{T}$ cell activation, clonal expansion and effector functions [35].

\section{Synovial Fibroblasts}

There is growing evidence that activated synovial fibroblasts (SFs), largely present in rheumatoid synovium, are one of the main players in the destructive process of RA [36]. Once activated, SFs produce increased amount of cytokines, chemokines and matrix-degrading enzymes that inhibit the contact with neighboring inflammatory and endothelial cells, which leads to destruction of articular cartilage and bone [37]. In this way, the production of cytokines and chemokines helps to recruit macrophages, neutrophils and $\mathrm{T}$ cells or the rheumatoid synovium, which attract more inflammatory cells and, which, in turn, increase the activated state of the SFs and of osteoclasts [1].

\section{Osteoclasts}

Osteoclasts are the prime bone resorbing cells, vital for the remodeling of bone throughout life. These multinucleated cells of hematopoietic origin have two key molecular machineries, essential to their bone resorb function [38]. Osteoclasts utilize a proton pump to acidify the environment deep to the ruffled border and solubilize mineral from bone. In addition, proteolytic enzymes including matrix metalloproteinases (MMPs) and cathepsin $\mathrm{K}$ are secreted that degrade the organic bone matrix [39].

\section{Chondrocytes}

Chondrocytes are a cell population exclusive of adult human articular cartilage, which covers the articulating surfaces of long bones. Under physiological conditions, the chondrocytes keep a constant balance between the synthesis and the degradation of matrix components [40]. However, influenced by synovial cytokines (mainly IL-1 and IL-17A) and reactive nitrogen species, cartilage is gradually deprived of chondrocytes, resulting in apoptosis [14].

\section{Macrophages}

Macrophages are of vital importance in the pathogenesis of RA, due to their higher presence in the inflamed synovial membrane, their activation status and their successful reaction to antirheumatic therapy [1, 41]. Activated macrophages display different phenotypes depending on the nature of the recruiting stimulus and the location [42]. Activated macrophages may release cytokines (IL-1, IL-6, TNF $\alpha$ ), chemokines (e.g, monocyte chemotactic protein-1, MCP-1/CCL2), digestive enzymes (e.g, collagenases), prostaglandins, and reactive oxygen species (ROS), responsible for damage of the normal tissues [43]. Moreover, activated macrophages contribute to the activation and proliferation of antigen specific T-cells due to their participation in antigen presentation [44]. 


\section{Current RA Therapy}

The treatment of RA in the last years is characterized by a firm evolution of new agents and new approaches [45]. Progress in knowledge about cellular and molecular mechanisms of RA and the development of new therapies have altered the overview of scientific community about RA. Discoveries concerning its pathogenesis have led to the development of new agents with specific molecular targets, which have changed the prognosis for numerous RA patients. Treatment paradigms in RA have shifted dramatically from controlling symptoms (using nonsteroidal antiinflammatory drugs, NSAIDs, and corticosteroids) to controlling the disease course with the suppression of inflammation (disease-modifying antirheumatic drugs, DMARDs, and biologics) [17]. This change in RA management results from growing evidences suggesting that early RA identification and treatment with DMARDs lead to improved prognosis and outcomes. Therefore, the aims of RA management, besides disease remission, also include an improved functional status. This issue can be assessed by radiographic joint damage, an important analysis for the impact that the initiation of suitable treatment during early RA has on these outcomes is essential [46]. The present treatment objective in RA is to reach permanent, and complete disease suppression leading in remission or even cure. Remission stops damage, prevents disability, increases quality of life and lowers mortality rates. Remission should be defined as the absence of disease activity, reflected as no clinical sign of synovitis, the elimination of smoldering, clinically silent synovial inflammation, and the control of acute-phase response. However, even constant "low-grade inflammation" is related to the possibility of comorbidities and increased mortality in RA [17].

Pain relief is an important achievement in RA therapy, but is only partly achieved by NSAIDs or opioids drugs, which do not have any influence on the autoimmune character of the disease. However, glucocorticoids and immunosuppressive agents, normally used in combination to reduce pain and inflammation in short-term, are capable of achieving some clinical remission. Over an extended period of time, higher doses can induce severe side effects. Therefore, agents that possess the ability to constantly reduce inflammation and, therefore, maintain joint integrity, with minor side effects, are preferred for the treatment of RA [47].

DMARDs form two main categories: synthetic chemical compounds (sDMARDs) and biological agents (bDMARDs). Due to the latest development, a new nomenclature for DMARDs has been recently proposed [48]. Therefore, the conventional sDMARDs (csDMARDs) will be applied to chemical agents such as methotrexate (MTX), sulfasalazine and leflunomide. In turn, tofacitinib, a new sDMARD to target JAKs, will be nominated as a targeted sDMARD (tsDMARD). The TNF inhibitors (adalimumab, certolizumab pegol, etanercept, golimumab and infliximab), the $\mathrm{T}$ cell costimulation inhibitor (abatacept), the anti-B cell agent (rituximab) and the IL-6 receptor (IL-6R)blocking monoclonal antibody (tocilizumab) as well as the IL-1 inhibitor (anakinra) will be termed as biological originator (bo) DMARDs. Finally, the biosimilars (bs) therapeutic agents, such as bsinfliximab, recently approved by the European Medicines Agency (EMA), will be designated as bsDMARDs [49].

\section{Synthetic DMARDs}

Of the many effective antirheumatic drugs available nowadays, DMARDs constitute the basis of treatment. Currently available DMARDs include synthetic or chemical drugs (Table 2), of which EULAR recommends three due to their efficacy and safety profile: MTX, leflunomide and sulfasalazine [3]. In turn, parenteral gold salts and antimalarial agents (such as hydroxychloroquine and chloroquine) are used most commonly in combination with other synthetic DMARDs, rarely as monotherapy [3]. Tofacitinib, a new synthetic DMARD, is a Janus kinase (JAK) inhibitor blocking downstream signaling for several cytokines integral to lymphocyte function [50]. Although it was the first synthetic DMARD approved by the Food and Drug Administration (FDA) for RA therapy, as well as regulatory agencies in several countries, the EMA did not approve this drug [51]. 
Table 2. Mode of action of synthetic DMARDs therapies used in RA.

\begin{tabular}{|c|c|c|}
\hline Drug & Target & Function of target and effect \\
\hline Methotrexate & $\begin{array}{c}\text { Folate-dependent enzymes (DHFR, } \\
\text { TS, ATIC) }\end{array}$ & $\begin{array}{c}\text { DHFR, TS and ATIC } \downarrow \text { : impaired pyrimidine and purine synthesis } \\
\text { leads to inhibition of lymphocyte proliferation AICAR } \uparrow: \text { high } \\
\text { adenosine levels show anti inflammatory effects }\end{array}$ \\
\hline Leflunomide & DHODH & $\begin{array}{c}\text { DHODH } \downarrow \text { : impaired pyrimidine synthesis leads to inhibition of } \\
\text { lymphocyte proliferation }\end{array}$ \\
\hline Sulfasalazine & Folate-dependent enzymes & $\begin{array}{l}\text { Unclear mechanism of action; inhibition of folate-dependent enzymes } \\
\text { was observed (see MTX); further described effects are: blockade of } \\
\text { IאB and induction of apoptosis of neutrophils and macrophages }\end{array}$ \\
\hline Gold salts & $\begin{array}{l}\text { Interaction with sulfur-containing } \\
\text { amino acids in plasma or } \\
\text { intracellular proteins }\end{array}$ & Inhibition of signal transduction and antigen presentation \\
\hline (Hydroxy)chloroquine & $\begin{array}{l}\text { Lysosomes, lysosomal enzymes, } \\
\text { TLR-9 }\end{array}$ & $\begin{array}{l}\text { Lysomotropic properties hinder antigen presentation Impaired } \\
\text { activation of the innate immune system }\end{array}$ \\
\hline Tofacitinib & $\begin{array}{c}\text { JAK1 and JAK3 (>JAK2 and } \\
\text { TYK) }\end{array}$ & $\begin{array}{c}\text { Leukocyte maturation and activation } \downarrow \text { Cytokine and immunoglobulin } \\
\text { production } \downarrow\end{array}$ \\
\hline
\end{tabular}

$\downarrow:$ Decrease; $\uparrow:$ Increase; DHFR: Dihydrofolate reductase; DHODH: Dehydroorotate dehydrogenase; TS: Thymidilate synthase; I B: inhibitor of kappa B; TYK: tyrosine-protein kinase

MTX is the first line therapy indicated for the treatment of RA. MTX is an analogue of folate and, hence, has structural and physiochemical properties considerably similar to those of folate; it has two carboxyl groups in its molecule and both of them are most completely dissociated in the physiological conditions [52]. It is unable to cross biological membranes in the body by simple diffusion, due their hydrophilicity, suggesting involvement of a carrier-mediated transport system. In this way, several transporters that are able to mediate the transport of MTX have been identified [52].

The study of MTX started in 1948, when Sidney Farber reports the successful use of aminopterin, an anti-folate in the treatment of childhood leukemia. To facilitate the manufacturing of aminopterin, the compound was modified, leading to the synthesis of MTX [53]. However, in 1950, Phillip Hench received the Noble Prize for has study of corticosteroids in RA and the clinical community lost the interest in the MTX treatment in RA [53]. Only in 1962, MTX was introduced for the psoriatic arthritis therapy, based on the erroneous supposition of eventual interference with the proliferation of connective tissues [45]. MTX was only approved for RA treatment in 1988, after two studies in which a total of 224 patient where treated for a maximum of 24 weeks [54, 55].

The effects of MTX can be explained by several mechanisms, namely (i) inhibition of purine and pyrimidine synthesis, leading to inhibition of proliferation of the inflammatory synovial cells; (ii) inhibition of the synthesis of polyamines; (iii) alterations in cellular redox state and decrease in intracellular glutathione levels, resulting in reduced macrophage and lymphocyte recruitment function and improved apoptosis sensitivity; and (iv) inhibition of the enzyme aminoimidazole carboxamide ribonucleotide (AICAR) transformilase (ATIC), consequent in higher AICAR cellular levels, resulting in the inhibition of AMP deaminase and finally leading to high levels of extracellular adenosine [17].

\section{Biological DMARDs}

At the end of the century, the RA treatment overview changed with the introduction of biologic targeted therapies. These therapeutic agents include monoclonal antibodies (mAbs) and genetically modified proteins targeted against cytokines or cellsurface molecules [56]. The identification of TNF as a vital player in the inflammatory process of the disease constitutes a milestone for key molecules and cells involved in RA pathogenesis as targeted therapies. Advances in knowledge of the role of $\mathrm{T}$ cells, B cells and cytokines such as IL-1 and IL-6 have contributed to the production of further biological agents, such as abatacept, rituximab, anakinra and tocilizumab, all approved after trials 
performed against MTX (Table 3). Over the last years of experience, bDMARDs demonstrated a good efficacy and safety in RA patients and are today used worldwide in clinical practice [45].

Table 3. Overview of the currently available biologic DMARDs for the treatment of RA $[47,51,56]$.

\begin{tabular}{|c|c|c|c|c|}
\hline Name & Target & Structure & Mechanism & Administration \\
\hline Etanercept & TNF & $\begin{array}{l}\text { Recombinant human fusion } \\
\text { protein of the TNF receptor and } \\
\text { the Fc portion of IgG1. }\end{array}$ & $\begin{array}{c}\text { Works as a decoy receptor. It } \\
\text { binds to soluble TNF, blocking } \\
\text { the binding to its receptor }\end{array}$ & s.c. injection; 50mg weekly \\
\hline Adalimumab & TNF & Fully human IgG1 mAb & Binding to TNF & s.c. injection; 40mg every other week \\
\hline Infliximab & TNF & $\begin{array}{l}\text { Chimeric murine-human IgG1 } \\
\qquad \mathrm{mAb}\end{array}$ & $\begin{array}{l}\text { Binding to soluble and mb } \\
\text { bound TNF }\end{array}$ & $\begin{array}{l}\text { i.v. infusion; for patients with RA, } \\
\text { dosing is } 3 \mathrm{mg} / \mathrm{kg} \text { at weeks } 0,2 \text { and } \\
6 \text {, then every } 8 \text { weeks }\end{array}$ \\
\hline Golimumab & TNF & Fully human IgG1 mAb & $\begin{array}{l}\text { Binding to soluble and } \mathrm{mb} \\
\text { bound TNF }\end{array}$ & s.c. injection; 50mg monthly \\
\hline $\begin{array}{c}\text { Certolizumab } \\
\text { pegol }\end{array}$ & TNF & $\begin{array}{l}\text { Humanized pegylated anti-TNF } \\
\text { Fab' fragment }\end{array}$ & Binding to TNF & $\begin{array}{l}\text { s.c. injection; } 400 \mathrm{mg} \text { initially, then } \\
200 \mathrm{mg} \text { every other week }\end{array}$ \\
\hline Anakinra & IL-1 & $\begin{array}{l}\text { Recombinant human IL-1 } \\
\text { receptor antagonist }\end{array}$ & $\begin{array}{l}\text { Binding to IL-1 type-1 } \\
\text { receptor }\end{array}$ & s.c. injection once a day \\
\hline Tocilizumab & IL-6 & $\begin{array}{l}\text { Humanized recombinant IgG1 } \\
\qquad \mathrm{mAb}\end{array}$ & $\begin{array}{l}\text { Binding to soluble and } \\
\text { membrane bound IL- } 6 \\
\text { receptor }\end{array}$ & $\begin{array}{l}\text { i.v. infusion; in patients with RA, } 8 \\
\mathrm{mg} / \mathrm{kg} \text { every } 4 \text { weeks }\end{array}$ \\
\hline Rituximab & $B$ cells & $\begin{array}{l}\text { Chimeric murine-human IgG1 } \\
\qquad \mathrm{mAb}\end{array}$ & $\begin{array}{c}\text { Binding to CD20 and } \\
\text { depletion of CD20+ B cells }\end{array}$ & $\begin{array}{l}\text { Two } 1000 \mathrm{mg} \text { i.v. infusions } 2 \text { weeks } \\
\text { apart every } 24 \text { weeks or more } \\
\text { frequently depending on disease } \\
\text { activity }\end{array}$ \\
\hline Abatacept & $T$ cells & $\begin{array}{l}\text { Recombinant human fusion } \\
\text { protein of the extracellular } \\
\text { domain of CTLA- } 4 \text { and the Fc } \\
\text { portion of IgG1 }\end{array}$ & $\begin{array}{l}\text { Binding to CD80/CD86, } \\
\text { blocking T-cell co-stimulation }\end{array}$ & $\begin{array}{l}\text { iv. infusion every } 4 \text { weeks or sc. } \\
\text { injection once a week }\end{array}$ \\
\hline
\end{tabular}

s.c.: subcutaneous; i.v.: intravenous; CTLA: cytotoxic T-lymphocyte-associated protein

The interest of companies in the development of "biosimilars" has increased lately, due to the fact that patents for several biological agents with expire in the near future. Once these alternatives become cheapest, they could be translated into a more cost-effective RA therapy and allow access to biologics for inumerous RA patients worldwide [51]. In September 2013, infliximab-biosimilar therapy (CT-P13, Trade names: Remsima and Inflectra) was licensed in the EU for the treatment of RA [57]. Biosimilar infliximab products show similar efficacy and safety profiles to the original biological agent, and present similar therapeutic properties to other TNF inhibitors [49].

\section{Recommendations for the RA Treatment}

In the last years, the ACR and the EULAR published recommendations for the use of cDMARDs and bDMARDs in RA treatment [49, 58]. In 2013, EULAR provided these updated recommendations following the same methodology used to develop the 2010 RA recommendations [59]. Some of the previous recommendations were deleted, and others were edited or divided. The items intent is to define the initiation of DMARD treatment using a csDMARD strategy in combination with glucocorticoids, followed by the addition of a bDMARD or another csDMARD strategy if any improvement is seen at 3 months, or the treatment target is not reached within 6 months. TNF inhibitors, abatacept, tocilizumab and, under defined conditions, rituximab are principally considered to have comparable efficacy and safety. If the first bDMARD agent fails, any other bDMARD may be used. The tsDMARD tofacitinib is also recommended (if licensed), after use of at least one bDMARD. Biosimilars are also addressed [49].

The EULAR Task Force aimed to discriminate some generic principles of treating RA from individual recommendations on individual thera- 
peutic approaches. This discussion resulted in 14 recommendations, which reflect the balance of efficacy and safety of DMARDs. Except for the first two items, which are the cornerstone of the therapeutic approach to RA, they are not listed by an importance order, but follow a rational sequence and procedural hierarchy [49].

\section{Animal Models}

Animal models of several human disorders have been developed with the aim of establishing effective and safe therapies. These experimental models are, mostly, induced by immunization with an antigen supposed participating in the analogous human disease [60].

Although several species have been used over the years (Table 4), rodent models of RA (both rats and mice) are the most common. This fact is due to the price, uniformity of the genetic background, and in mice, the ability to use genetically modified strains. Most RA animal models are based on an inducing agent, and even "spontaneous" models can be considered induced since they develop the disease upon the addition or deletion of specific genes in animals with a suitable immunologic susceptibility [61].

Table 4. Mouse models for RA [64].

\begin{tabular}{|c|c|c|c|}
\hline Model type & Disease name & Induction agent/ target gene for manipulation & $\begin{array}{c}\text { Disease } \\
\text { characteristics }\end{array}$ \\
\hline $\begin{array}{c}\text { Induced } \\
\text { arthritis } \\
\text { models }\end{array}$ & $\begin{array}{c}\text { Staphylococcus aureus-induced } \\
\text { arthritis }\end{array}$ & $\begin{array}{c}\text { Toxic shock syndrome toxin-1-producing } S \text {. aureus } \\
\text { LS-1 strain }\end{array}$ & Acute \\
\cline { 2 - 4 } & $\begin{array}{c}\text { Borrelia burgdorferi-associated } \\
\text { arthritis }\end{array}$ & Borrelia burgdorferi & Acute \\
\cline { 2 - 4 } & CIA & Heterologous CII & Acute/chronic \\
\cline { 2 - 4 } & Proteoglycan-induced arthritis & Human cartilage proteoglycan & Acute to chronic \\
\cline { 2 - 4 } & Pristane-induced arthritis & Pristane (2,6,10,14-tetramethylpentadecane) & Chronic \\
\cline { 2 - 4 } & Anti-CII antibody-induced arthritis & Transfer of CII specific antibodies & Acute \\
\cline { 2 - 4 } & $\begin{array}{c}\text { Anti-GPI antibody transfer-induced } \\
\text { arthritis }\end{array}$ & Transfer of GPI-specific polyclonal antibodies & Acute \\
\hline \multirow{4}{*}{$\begin{array}{c}\text { Genetically } \\
\text { manipulated } \\
\text { models }\end{array}$} & TNF- $\alpha$ transgenic & Human tumor necrosis factor & Acute \\
\cline { 2 - 4 } & IL-1Ra ${ }^{-r}$ & IL-1 receptor antagonist & Chronic \\
\cline { 2 - 4 } & HTLV-1 env-pX transgenic & HTLV-1 env-pX & Chronic \\
\cline { 2 - 4 } & K/BxN TCR transgenic & KRN peptide specific TCR & Chronic \\
\hline
\end{tabular}

HTLV: Human T-Cell Leukemia Virus; TCR: T-cell receptor; KRN: $\mathrm{H}^{k}$ restricted bovine ribonuclease

\section{Collagen-Induced Arthritis Model}

Among the aforementionated animal models for RA, collagen-induced arthritis (CIA) in DBA/1 mice is the most commonly used. The first report dates back to 1977, when Trentham and colleagues described that immunization of rats with an emulsion of type II collagen (CII) in complete Freund's adjuvant (CFA) assisted in the development of an erosive polyarthritis related to autoimmune response against cartilage [62]. Later, other researchers have developed similar methods for the development of CIA in mice [63].

Several autoimmune disorders include the manifestation of autoimmunity to autologous proteins which have been tested for autoreactive $\mathrm{T}$ cells and antibodies in both human disease and animal models. In line with this, CII is one of the key autoantigens of human RA based on high amounts of anti-CII antibodies and CII-specific T cells detected in these patients. This higher prevalence, noted particularly during the early stage of RA, indicates that CII-specific immunity plays a key role in the beginning of inflammation in the articular joints. Since CII is the major constituent protein only expressed in the articular cartilage of joints, the immunity developed against the CII of heterologous species may induce joint destruction [65]. Similarly to RA, CIA mice susceptibility is associated with the expression of specific MHC class II molecules, specifically, I-Aq and I-Ar in the mouse, and HLA-DR1 and -DR4 in humans [66]. 
CIA is easily induced after just one immunization with heterologous CII. This process boosts the immune system after few days, followed by immune activation in the joints after 1-2 weeks and an abrupt establishment of macroscopic arthritis just after 2 weeks, which can be maintained for several months after immunization. Within a few days after disease establishment, an inflammatory reaction damages the joint, with a very similar histopathology as observed in humans (Table 5). Active inflammation will decrease 3-4 weeks after disease establishment, leaving behind a destroyed joint behind, but without inflammation [67].

CIA reacts poorly to NSAIDs or MTX, and is mainly unresponsive by gold salts, chloroquine, colchicine or levamisole. The reduced NSAID activity in CIA is considered as an additional advantage over other arthritis models [68].

Table 5. Similarities and differences between human RA and CIA in DBA/1 Mice [63].

\begin{tabular}{|c|c|c|}
\hline & $\mathbf{R A}$ & CIA \\
\hline \multirow[t]{4}{*}{ Similarities } & Polyarticular & Polyarticular \\
\hline & $\begin{array}{l}\text { Predisposition to RA is associated with certain MHC-II } \\
\text { haplotypes }\end{array}$ & $\begin{array}{l}\text { Susceptibility to CIA is associated with certain } \mathrm{H}-2 \\
\text { complex }\end{array}$ \\
\hline & $\begin{array}{c}\text { Joint pathology: } \\
\text { Hyperplasia of synovial membrane } \\
\text { Synovial immune infiltration } \\
\text { Neutrophils in synovial fluid } \\
\text { Pannus formation } \\
\text { Bone destruction by osteoclasts } \\
\end{array}$ & $\begin{array}{c}\text { Joint pathology: } \\
\text { Hyperplasia of synovial membrane } \\
\text { Synovial immune infiltration } \\
\text { Neutrophils in synovial fluid } \\
\text { Pannus formation } \\
\text { Bone destruction by osteoclasts } \\
\end{array}$ \\
\hline & $\begin{array}{c}\text { Serological markers: } \\
\text { Rheumatoid factor } \\
\text { Anti-CII antibodies } \\
\text { Anticyclic citrullinated peptide antibodies }\end{array}$ & $\begin{array}{c}\text { Serological markers: } \\
\text { Rheumatoid factor } \\
\text { Anti-CII antibodies } \\
\text { Anticyclic citrullinated peptide antibodies }\end{array}$ \\
\hline \multirow[t]{3}{*}{ Differences } & Symmetric joint involvement & Nonsymmetric joint involvement \\
\hline & Chronic & Transient \\
\hline & Systemic/extra-articular manifestations & No reports about systemic manifestations \\
\hline
\end{tabular}

\section{CONCLUSION}

Significant advances have been made in our knowledge about RA over the past decades. Valuable new information has been obtained from epidemiologic and genetic investigations, which has allowed the identification of pathogenic and regulatory components. Rheumatoid synovitis is a complex process in which loss in self-tolerance results in anomalies including recognition of citrullinated antigens by $\mathrm{B}$ and $\mathrm{T}$ cells. The identification of biological markers, allows the implementation of new RA classification criteria, to include patients at the earliest stages of disease, reducing their activity, preventing joint destruction and preserving physical function.

The discovery and targeting of novel pertinent pathways in the pathogenesis of RA created a huge opportunity of controlling this disease. It has been highlighted how the human genetic data can be efficiently integrated with other biological information to originate biological insights and drive drug discovery. Indeed, comprehensive genetic studies shed light on fundamental genes, pathways and cell types that contribute to RA pathogenesis, and provide empirical evidence that the genetics of RA can provide important information about drug discovery, and personal treatment of RA patients.

Further, knowledge of the mechanisms of action of DMARDs has contributed to the development of more effective therapy strategies. Biologic agents, the newer group of DMARDS, have improved the treatment outcome of patients. However, the higher cost is limiting their use. In this way, more efficient strategies have to be identified in order to improve inflammatory disease treatments while decreasing the side effects with an improved cost-benefit ratio.

Animal models have been a valuable tool, because they enable the establishment of more accurate models to predict the several precise 
variants of human autoimmune diseases including the early starting phase. In this way, we can be confident that the near future will provide the means for effective treatment efficiently of RA patients.

\section{LIST OF ABBREVIATIONS}

$$
\begin{aligned}
& \text { ACPA }=\text { Anti-Citrullinated Peptide } \\
& \text { ACR = American College of Rheumatology } \\
& \text { AICAR = Aminoimidazole Carboxamide Ribonucleo- } \\
& \text { tide } \\
& \text { ATIC }=\text { AICAR Transformilase } \\
& \text { bDMARD }=\text { Biological DNARD } \\
& \text { bSDMARD }=\text { Biosimilars DMARD } \\
& \text { CCP = Cyclic Citrullinated Peptide } \\
& \text { CFA }=\text { Complete Freund's Adjuvant } \\
& \text { CIA }=\text { Collagen Induced Arthritis } \\
& \text { CII = Type II Collagen } \\
& \text { csDMARD }=\text { Conventional sDMARD } \\
& \text { CTLA = Cytotoxic T-Lymphocyte-Associated Protein } \\
& \text { DHFR = Dihydrofolate Reductase } \\
& \text { DHODH = Dehydroorotate Dehydrogenase } \\
& \text { DMARD = Disease-Modifying Antirheumatic Drug } \\
& \text { EMA }=\text { European Medicines Agency } \\
& \text { EULAR = European League Against Rheumatism } \\
& \text { Fc } \quad=\text { Fragment Crystallizable } \\
& \text { FDA }=\text { Food and Drug Administration } \\
& \text { HLA = Human Leukocyte Antigen } \\
& \text { HTLV = Human T-Cell Leukemia Virus } \\
& \text { IFN }=\text { Interferon } \\
& \text { IgG = Imunoglobulina } \mathrm{G} \\
& \text { IкB = Inhibitor of Kappa B } \\
& \text { IL }=\text { Interleukin } \\
& \text { i.v. } \quad=\text { Intravenous } \\
& \text { JNK = Janus N-Terminal Kinase } \\
& \text { KRN }=\mathrm{H} 2^{\mathrm{k}} \text { Restricted Bovine Ribonuclease } \\
& \mathbf{m A b}=\text { Monoclonal antibody } \\
& \text { MCP = Monocyte Chemoattractant Protein } \\
& \text { MHC = Major Histocompatibility Complex } \\
& \text { MTX = Methotrexate } \\
& \text { NF-кB = Factor Nuclear Kappa B } \\
& \text { NSAID = Nonsteroidal Anti-Inflammatory Drug } \\
& \text { PTPN= Protein Tyrosine Phosphatase Nonreceptor } \\
& \text { RA }=\text { Rheumatoid Arthritis } \\
& \text { RF }=\text { Rheumatic Factor }
\end{aligned}
$$

$$
\begin{array}{ll}
\text { s.c. } & =\text { Subcutaneous } \\
\text { SDMARD } & =\text { Synthetic DMARD } \\
\text { SE } & =\text { Shared Epitope } \\
\text { SF } & =\text { Synovial Fibroblasts } \\
\text { STAT } & =\text { Signal Transducer and Activator of } \\
& \text { Transcription } \\
\text { TCR } & =\text { T-Cell Receptor } \\
\text { Th } & =\text { T Helper } \\
\text { TNF } & =\text { Tumour Necrosis Factor } \\
\text { TNFAIP3 }= & \text { TNF Alpha Induced Protein } 3 \\
\text { TRAF1/C5 } & =\text { TNF-Associated Factor } 1 \text { and Complement } \\
& \text { Component } C 5 \\
\text { TS } & =\text { Thymidilate Synthase } \\
\text { tsDMARD }= & \text { Targeted sDMARD } \\
\text { TYC } & =\text { Tyrosine-Protein Kinase }
\end{array}
$$

\section{CONFLICT OF INTEREST}

The authors confirm that this article content has no conflict of interest.

\section{ACKNOWLEDGEMENTS}

Eugénia Nogueira (SFRH/BD/81269/2011) holds a scholarship from Fundação para a Ciência e a Tecnologia (FCT). This study was funded by the European Union Seventh Framework Programme (FP7/2007-2013) under grant agreement NMP4LA-2009-228827 NANOFOL. The authors thank the FCT Strategic Project of UID/BIO/04469/2013 unit, the project RECI/BBB-EBI/0179/2012 (FCOMP-01-0124-FEDER-027462) and the Project "BioHealth - Biotechnology and Bioengineering approaches to improve health quality", Ref. NORTE-07-0124-FEDER-000027, co-funded by the Programa Operacional Regional do Norte (ON.2 - O Novo Norte), QREN, FEDER. This work was also supported by FCT I.P. through the strategic funding UID/BIA/04050/2013.

\section{REFERENCES}

[1] Shrivastava, A.K.; Pandey, A. Inflammation and rheumatoid arthritis. J. Physiol. Biochem., 2013, 69(2), 335-347. [http://dx.doi.org/10.1007/s13105-012-0216-5] [PMID: 23385669]

[2] Kourilovitch, M.; Galarza-Maldonado, C.; Ortiz-Prado, E. Diagnosis and classification of rheumatoid arthritis. $J$. Autoimmun., 2014, 48-49, 26-30. [http://dx.doi.org/10.1016/j.jaut.2014.01.027] [PMID: 24568777]

[3] Sanmartí, R.; Ruiz-Esquide, V.; Hernández, M.V. Rheumatoid arthritis: a clinical overview of new diagnostic and treatment approaches. Curr. Top. Med. Chem., 2013, 13(6), 698-704. 
[http://dx.doi.org/10.2174/15680266113139990092] [PMID: 23574518]

[4] Davis, J.M., III; Matteson, E.L. American College of Rheumatology; European League Against Rheumatism. My treatment approach to rheumatoid arthritis. Mayo Clin. Proc., 2012, 87(7), 659-673.

[http://dx.doi.org/10.1016/j.mayocp.2012.03.011] [PMID: 22766086]

[5] Kitas, G.D.; Gabriel, S.E. Cardiovascular disease in rheumatoid arthritis: state of the art and future perspectives. Ann. Rheum. Dis., 2011, 70(1), 8-14.

[http://dx.doi.org/10.1136/ard.2010.142133]

[PMID: 21109513]

[6] Koota, K.; Isomäki, H.; Mutru, O. Death rate and causes of death in RA patients during a period of five years. Scand. $J$. Rheumatol., 1977, 6(4), 241-244.

[http://dx.doi.org/10.3109/03009747709095458] [PMID: 607393]

[7] Myllykangas-Luosujärvi, R.A.; Aho, K.; Isomäki, H.A. Mortality in rheumatoid arthritis. Semin. Arthritis Rheum., 1995, 25(3), 193-202.

[http://dx.doi.org/10.1016/S0049-0172(95)80031-X] [PMID: 8650589]

[8] Imboden, J.B. The immunopathogenesis of rheumatoid arthritis. Annu. Rev. Pathol., 2009, 4(1), 417-434. [http://dx.doi.org/10.1146/annurev.pathol.4.110807.092254] [PMID: 18954286]

[9] Willemze, A.; Toes, R.E.; Huizinga, T.W.; Trouw, L.A. New biomarkers in rheumatoid arthritis. Neth. J. Med., 2012, 70(9), 392-399. [PMID: 23123533]

[10] Stahl, E.A.; Raychaudhuri, S.; Remmers, E.F.; Xie, G.; Eyre, S.; Thomson, B.P.; Li, Y.; Kurreeman, F.A.; Zhernakova, A.; Hinks, A.; Guiducci, C.; Chen, R.; Alfredsson, L.; Amos, C.I.; Ardlie, K.G.; Barton, A.; Bowes, J.; Brouwer, E.; Burtt, N.P.; Catanese, J.J.; Coblyn, J.; Coenen, M.J.; Costenbader, K.H.; Criswell, L.A.; Crusius, J.B.; Cui, J.; de Bakker, P.I.; De Jager, P.L.; Ding, B.; Emery, P.; Flynn, E.; Harrison, P.; Hocking, L.J.; Huizinga, T.W.; Kastner, D.L.; Ke, X.; Lee, A.T.; Liu, X.; Martin, P.; Morgan, A.W.; Padyukov, L.; Posthumus, M.D.; Radstake, T.R.; Reid, D.M.; Seielstad, M.; Seldin, M.F.; Shadick, N.A.; Steer, S.; Tak, P.P.; Thomson, W.; van der Helm-van Mil, A.H.; van der Horst-Bruinsma, I.E.; van der Schoot, C.E.; van Riel, P.L.; Weinblatt, M.E.; Wilson, A.G.; Wolbink, G.J.; Wordsworth, B.P.; Wijmenga, C.; Karlson, E.W.; Toes, R.E.; de Vries, N.; Begovich, A.B.; Worthington, J.; Siminovitch, K.A.; Gregersen, P.K.; Klareskog, L.; Plenge, R.M. Genome-wide association study meta-analysis identifies seven new rheumatoid arthritis risk loci. Nat. Genet., 2010, 42(6), 508-514. [http://dx.doi.org/10.1038/ng.582] [PMID: 20453842]

[11] Okada, Y.; Wu, D.; Trynka, G.; Raj, T.; Terao, C.; Ikari, K.; Kochi, Y.; Ohmura, K.; Suzuki, A.; Yoshida, S.; Graham, R.R.; Manoharan, A.; Ortmann, W.; Bhangale, T.; Denny, J.C.; Carroll, R.J.; Eyler, A.E.; Greenberg, J.D.; Kremer, J.M.; Pappas, D.A.; Jiang, L.; Yin, J.; Ye, L.; Su, D.F.; Yang, J.; Xie, G.; Keystone, E.; Westra, H.J.; Esko, T.; Metspalu, A.; Zhou, X.; Gupta, N.; Mirel, D.; Stahl, E.A.; Diogo, D.; Cui, J.; Liao, K.; Guo, M.H.; Myouzen, K.; Kawaguchi, T.; Coenen, M.J.; van Riel, P.L.; van de Laar, M.A.; Guchelaar, H.J.; Huizinga, T.W.; Dieudé, P.; Mariette, X.; Bridges, S.L., Jr; Zhernakova, A.; Toes, R.E.; Tak, P.P.; Miceli-Richard, C.; Bang, S.Y.; Lee, H.S.; Martin, J.; Gonzalez-Gay, M.A.; Rodriguez-Rodriguez, L.; Rantapä-Dahlqvist, S.; Arlestig, L.; Choi, H.K.; Kamatani, Y.; Galan, P.; Lathrop, M.; Eyre, S.; Bowes, J.; Barton, A.; de Vries, N.; Moreland, L.W.; Criswell, L.A.; Karlson, E.W.; Taniguchi, A.; Yamada, R.;
Kubo, M.; Liu, J.S.; Bae, S.C.; Worthington, J.; Padyukov, L.; Klareskog, L.; Gregersen, P.K.; Raychaudhuri, S.; Stranger, B.E.; De Jager, P.L.; Franke, L.; Visscher, P.M.; Brown, M.A.; Yamanaka, H.; Mimori, T.; Takahashi, A.; Xu, H.; Behrens, T.W.; Siminovitch, K.A.; Momohara, S.; Matsuda, F.; Yamamoto, K.; Plenge, R.M. Genetics of rheumatoid arthritis contributes to biology and drug discovery. Nature, 2014, 506(7488), 376-381. [http://dx.doi.org/10.1038/nature12873] [PMID: 24390342]

[12] Suzuki, A.; Kochi, Y.; Okada, Y.; Yamamoto, K. Insight from genome-wide association studies in rheumatoid arthritis and multiple sclerosis. FEBS Lett., 2011, 585(23), 3627-3632. [http://dx.doi.org/10.1016/j.febslet.2011.05.025] [PMID: 21600898]

[13] Saad, M.N.; Mabrouk, M.S.; Eldeib, A.M.; Shaker, O.G. Identification of rheumatoid arthritis biomarkers based on single nucleotide polymorphisms and haplotype blocks: A systematic review and meta-analysis. J. Adv. Res., 2016, 7(1), 1-16.

[http://dx.doi.org/10.1016/j.jare.2015.01.008]

[PMID: 26843965]

[14] McInnes, I.B.; Schett, G. The pathogenesis of rheumatoid arthritis. N. Engl. J. Med., 2011, 365(23), 2205-2219. [http://dx.doi.org/10.1056/NEJMra1004965] 22150039]

[15] Boissier, M.C.; Semerano, L.; Challal, S.; SaidenbergKermanac'h, N.; Falgarone, G. Rheumatoid arthritis: from autoimmunity to synovitis and joint destruction. $J$. Autoimmun., 2012, 39(3), 222-228. [http://dx.doi.org/10.1016/j.jaut.2012.05.021]

[PMID: 22704962]

[16] Arnett, F.C.; Edworthy, S.M.; Bloch, D.A.; McShane, D.J.; Fries, J.F.; Cooper, N.S.; Healey, L.A.; Kaplan, S.R.; Liang, M.H.; Luthra, H.S. The American Rheumatism Association 1987 revised criteria for the classification of rheumatoid arthritis. Arthritis Rheum., 1988, 31(3), 315-324. [http://dx.doi.org/10.1002/art.1780310302] [PMID: 3358796]

[17] Colmegna, I.; Ohata, B.R.; Menard, H.A. Current understanding of rheumatoid arthritis therapy. Clin. Pharmacol. Ther., 2012, 91(4), 607-620. [http://dx.doi.org/10.1038/clpt.2011.325] [PMID: 22357455]

[18] Deane, K.D. Preclinical rheumatoid arthritis (autoantibodies): an updated review. Cur. Rheumatol. Rep., 2014, 16(5), 14-41.

[19] Aletaha, D.; Neogi, T.; Silman, A.J.; Funovits, J.; Felson, D.T.; Bingham, C.O., III; Birnbaum, N.S.; Burmester, G.R.; Bykerk, V.P.; Cohen, M.D.; Combe, B.; Costenbader, K.H.; Dougados, M.; Emery, P.; Ferraccioli, G.; Hazes, J.M.; Hobbs, K.; Huizinga, T.W.; Kavanaugh, A.; Kay, J.; Kvien, T.K.; Laing, T.; Mease, P.; Ménard, H.A.; Moreland, L.W.; Naden, R.L.; Pincus, T.; Smolen, J.S.; Stanislawska-Biernat, E.; Symmons, D.; Tak, P.P.; Upchurch, K.S.; Vencovský, J.; Wolfe, F.; Hawker, G. 2010 Rheumatoid arthritis classification criteria: an American College of Rheumatology/European League Against Rheumatism collaborative initiative. Arthritis Rheum., 2010, 62(9), 2569-2581.

[http://dx.doi.org/10.1002/art.27584] [PMID: 20872595]

[20] Kay, J.; Upchurch, K.S. ACR/EULAR 2010 rheumatoid arthritis classification criteria. Rheumatology (Oxford), 2012, 51(Suppl. 6), vi5-vi9.

[http://dx.doi.org/10.1093/rheumatology/kes279] [PMID: 23221588]

[21] Holmdahl, R.; Malmström, V.; Burkhardt, H. Autoimmune priming, tissue attack and chronic inflammation - the three stages of rheumatoid arthritis. Eur. J. Immunol., 2014, 44(6), 1593-1599.

[http://dx.doi.org/10.1002/eji.201444486] [PMID: 24737176] 
[22] Smolen, J.S.; Steiner, G. Therapeutic strategies for rheumatoid arthritis. Nat. Rev. Drug Discov., 2003, 2(6), 473-488.

[http://dx.doi.org/10.1038/nrd1109] [PMID: 12776222]

[23] Choy, E. Understanding the dynamics: pathways involved in the pathogenesis of rheumatoid arthritis. Rheumatology (Oxford), 2012, 51(51)(Suppl. 5), v3-v11.

[http://dx.doi.org/10.1093/rheumatology/kes113] [PMID: 22718924]

[24] Alunno, A.; Manetti, M.; Caterbi, S.; Ibba-Manneschi, L.; Bistoni, O.; Bartoloni, E.; Valentini, V.; Terenzi, R.; Gerli, R. Altered immunoregulation in rheumatoid arthritis: the role of regulatory $\mathrm{T}$ cells and proinflammatory Th17 cells and therapeutic implications. Mediators Inflamm., 2015, 2015, 751793. [http://dx.doi.org/10.1155/2015/751793] [PMID: 25918479]

[25] Noack, M.; Miossec, P. Th17 and regulatory T cell balance in autoimmune and inflammatory diseases. Autoimmun. Rev., 2014, 13(6), 668-677.

[http://dx.doi.org/10.1016/j.autrev.2013.12.004] [PMID: 24418308]

[26] Son, H.J.; Lee, J.; Lee, S.Y.; Kim, E.K.; Park, M.J.; Kim, K.W.; Park, S.H.; Cho, M.L. Metformin attenuates experimental autoimmune arthritis through reciprocal regulation of Th17/Treg balance and osteoclastogenesis. Mediators Inflamm., 2014, 2014(10), 973986. [PMID: 25214721]

[27] Trifari, S.; Kaplan, C.D.; Tran, E.H.; Crellin, N.K.; Spits, H. Identification of a human helper $\mathrm{T}$ cell population that has abundant production of interleukin 22 and is distinct from $\mathrm{T}(\mathrm{H})-17, \mathrm{~T}(\mathrm{H}) 1$ and $\mathrm{T}(\mathrm{H}) 2$ cells. Nat. Immunol., 2009, 10(8), 864-871. [http://dx.doi.org/10.1038/ni.1770] [PMID: 19578368]

[28] Zhang, L.; Li, Y.G.; Li, Y.H.; Qi, L.; Liu, X.G.; Yuan, C.Z.; Hu, N.W.; Ma, D.X.; Li, Z.F.; Yang, Q.; Li, W.; Li, J.M. Increased frequencies of Th22 cells as well as Th17 cells in the peripheral blood of patients with ankylosing spondylitis and rheumatoid arthritis. PLoS One, 2012, 7(4), e31000. [http://dx.doi.org/10.1371/journal.pone.0031000] [PMID: 22485125]

[29] Zhang, L.; Li, J.M.; Liu, X.G.; Ma, D.X.; Hu, N.W.; Li, Y.G.; Li, W.; Hu, Y.; Yu, S.; Qu, X.; Yang, M.X.; Feng, A.L.; Wang, G.H. Elevated Th22 cells correlated with Th17 cells in patients with rheumatoid arthritis. J. Clin. Immunol., 2011, 31(4), 606-614.

[http://dx.doi.org/10.1007/s10875-011-9540-8] [PMID: 21556937]

[30] van Hamburg, J.P.; Corneth, O.B.; Paulissen, S.M.; Davelaar, N.; Asmawidjaja, P.S.; Lubberts, E. Th17 but not Th22 cells display pathological behaviour in arthritis. Ann. Rheum. Dis., 2012, 71(Suppl. 1), A89. [http://dx.doi.org/10.1136/annrheumdis-2011-201239.9]

[31] Talotta, R.; Berzi, A.M.; Atzeni, F.; Dell'Acqua, D.; Trabattoni, D.; Sarzi-Puttini, P. AB0429 The Role of TH9 Lymphocytes in Rheumatoid Arthritis. Ann. Rheum. Dis., 2015, 74(Suppl. 2), 1037-1038.

[http://dx.doi.org/10.1136/annrheumdis-2015-eular.2791] [PMID: 24550168]

[32] Ciccia, F.; Guggino, G.; Rizzo, A.; Manzo, A.; Vitolo, B.; La Manna, M.P.; Giardina, G.; Sireci, G.; Dieli, F.; Montecucco, C.M.; Alessandro, R.; Triolo, G. Potential involvement of IL-9 and Th9 cells in the pathogenesis of rheumatoid arthritis. Rheumatology (Oxford), 2015, 54(12), 2264-2272.

[http://dx.doi.org/10.1093/rheumatology/kev252] [PMID: 26178600]

[33] Nogueira, E.; Gomes, A.C.; Preto, A.; Cavaco-Paulo, A. Folate-targeted nanoparticles for rheumatoid arthritis therapy.
Nanomed. Nanotechnol. Biol. Med., 2016, 12(4), 1113-26.

[34] Kim, H-J; Berek, C. B cells in rheumatoid arthritis. Arthritis Research \& Therapy, 2000, 2(2), 126-31.

[http://dx.doi.org/10.1186/ar77]

[35] Wang, Q.; Ma, Y.; Liu, D.; Zhang, L.; Wei, W. The roles of B cells and their interactions with fibroblast-like synoviocytes in the pathogenesis of rheumatoid arthritis. Int. Arch. Allergy Immunol., 2011, 155(3), 205-211. [http://dx.doi.org/10.1159/000321185] [PMID: 21293141]

[36] Lefèvre, S.; Knedla, A.; Tennie, C.; Kampmann, A.; Wunrau, C.; Dinser, R.; Korb, A.; Schnäker, E.M.; Tarner, I.H.; Robbins, P.D.; Evans, C.H.; Stürz, H.; Steinmeyer, J.; Gay, S.; Schölmerich, J.; Pap, T.; Müller-Ladner, U.; Neumann, E. Synovial fibroblasts spread rheumatoid arthritis to unaffected joints. Nat. Med., 2009, 15(12), 1414-1420. [http://dx.doi.org/10.1038/nm.2050] [PMID: 19898488]

[37] Huber, L.C.; Distler, O.; Tarner, I.; Gay, R.E.; Gay, S.; Pap, T. Synovial fibroblasts: key players in rheumatoid arthritis. Rheumatology (Oxford), 2006, 45(6), 669-675. [http://dx.doi.org/10.1093/rheumatology/kel065] [PMID: 16567358]

[38] Schett, G. Cells of the synovium in rheumatoid arthritis. Osteoclasts. Arthritis Res. Ther., 2007, 9(1), 203. [http://dx.doi.org/10.1186/ar2110] [PMID: 17316459]

[39] Shaw, AT; Gravallese, EM Mediators of inflammation and bone remodeling in rheumatic disease. Semin. Cell Dev. Biol., 2016, 49, 2-10. [http://dx.doi.org/10.1016/j.semcdb.2015.10.013]

[40] Otero, M.; Goldring, M.B. Cells of the synovium in rheumatoid arthritis. Chondrocytes. Arthritis Res. Ther., 2007, 9(5), 220.

[http://dx.doi.org/10.1186/ar2292] [PMID: 18001488]

[41] Baschant, U.; Lane, N.E.; Tuckermann, J. The multiple facets of glucocorticoid action in rheumatoid arthritis. Nat. Rev. Rheumatol., 2012, 8(11), 645-655.

[http://dx.doi.org/10.1038/nrrheum.2012.166] [PMID: 23045254]

[42] Maruotti, N.; Annese, T.; Cantatore, F.P.; Ribatti, D. Macrophages and angiogenesis in rheumatic diseases. Vasc. Cell, 2013, 5(1), 11.

[http://dx.doi.org/10.1186/2045-824X-5-11]

[PMID: 23725043]

[43] Xia, W.; Hilgenbrink, A.R.; Matteson, E.L.; Lockwood, M.B.; Cheng, J.X.; Low, P.S. A functional folate receptor is induced during macrophage activation and can be used to target drugs to activated macrophages. Blood, 2009, 113(2), 438-446.

[http://dx.doi.org/10.1182/blood-2008-04-150789] [PMID: 18952896]

[44] Paulos, C.M.; Turk, M.J.; Breur, G.J.; Low, P.S. Folate receptor-mediated targeting of therapeutic and imaging agents to activated macrophages in rheumatoid arthritis. Adv. Drug Deliv. Rev., 2004, 56(8), 1205-1217.

[http://dx.doi.org/10.1016/j.addr.2004.01.012] [PMID: 15094216]

[45] Favalli, E.G.; Biggioggero, M.; Meroni, P.L. Methotrexate for the treatment of rheumatoid arthritis in the biologic era: still an "anchor" drug? Autoimmun. Rev., 2014, 13(11), 1102-1108.

[http://dx.doi.org/10.1016/j.autrev.2014.08.026] [PMID: 25172238]

[46] Demoruelle, M.K.; Deane, K.D. Treatment strategies in early rheumatoid arthritis and prevention of rheumatoid arthritis. Curr. Rheumatol. Rep., 2012, 14(5), 472-480. [http://dx.doi.org/10.1007/s11926-012-0275-1] [PMID: 22773387]

[47] Meier, F.M.; Frerix, M.; Hermann, W.; Müller-Ladner, U. 
Current immunotherapy in rheumatoid arthritis. Immunotherapy, 2013, 5(9), 955-974. [http://dx.doi.org/10.2217/imt.13.94] [PMID: 23998731]

[48] Smolen, J.S.; van der Heijde, D.; Machold, K.P.; Aletaha, D.; Landewé, R. Proposal for a new nomenclature of diseasemodifying antirheumatic drugs. Ann. Rheum. Dis., 2014, 73(1), 3-5.

[http://dx.doi.org/10.1136/annrheumdis-2013-204317] [PMID: 24072562]

[49] Smolen, J.S.; Landewé, R.; Breedveld, F.C. EULAR recommendations for the management of rheumatoid arthritis with synthetic and biological disease-modifying antirheumatic drugs: 2013 update. Ann. Rheum. Dis., 2013. [PMID: 24161836]

[50] Scher, J.U. Monotherapy in rheumatoid arthritis. Bull. Hosp. Jt. Dis., 2013, 71(3), 204-207. [PMID: 24151946]

[51] Vivar, N.; Van Vollenhoven, R.F. Advances in the treatment of rheumatoid arthritis. F1000Prime Rep., 2014, 6, 31. [http://dx.doi.org/10.12703/P6-31] [PMID: 24860653]

[52] Inoue, K.; Yuasa, H. Molecular basis for pharmacokinetics and pharmacodynamics of methotrexate in rheumatoid arthritis therapy. Drug Metab. Pharmacokinet., 2014, 29(1), $12-19$

[http://dx.doi.org/10.2133/dmpk.DMPK-13-RV-119] [PMID: 24284432]

[53] Weinblatt, M.E. Methotrexate in rheumatoid arthritis: a quarter century of development. Trans. Am. Clin. Climatol. Assoc., 2013, 124, 16-25. [PMID: 23874006]

[54] Weinblatt, M.E.; Coblyn, J.S.; Fox, D.A.; Fraser, P.A.; Holdsworth, D.E.; Glass, D.N.; Trentham, D.E. Efficacy of low-dose methotrexate in rheumatoid arthritis. N. Engl. J. Med., 1985, 312(13), 818-822.

[http://dx.doi.org/10.1056/NEJM198503283121303] [PMID: 3883172]

[55] Williams, H.J.; Willkens, R.F.; Samuelson, C.O., Jr; Alarcón, G.S.; Guttadauria, M.; Yarboro, C.; Polisson, R.P.; Weiner, S.R.; Luggen, M.E.; Billingsley, L.M. Comparison of lowdose oral pulse methotrexate and placebo in the treatment of rheumatoid arthritis. A controlled clinical trial. Arthritis Rheum., 1985, 28(7), 721-730. [http://dx.doi.org/10.1002/art.1780280702] [PMID: 3893441]

[56] Upchurch, K.S.; Kay, J. Evolution of treatment for rheumatoid arthritis. Rheumatology (Oxford), 2012, 51(6)(Suppl. 6), vi28-vi36. [PMID: 23221584]

[57] Baji, P.; Péntek, M.; Czirják, L.; Szekanecz, Z.; Nagy, G.; Gulácsi, L.; Brodszky, V. Efficacy and safety of infliximabbiosimilar compared to other biological drugs in rheumatoid arthritis: a mixed treatment comparison. Eur. J. Health Econ., 2014, 15(Suppl. 1), S53-S64.

[http://dx.doi.org/10.1007/s10198-014-0594-4] [PMID: 24832836]

[58] Singh, J.A.; Furst, D.E.; Bharat, A.; Curtis, J.R.; Kavanaugh, A.F.; Kremer, J.M.; Moreland, L.W.; O’Dell, J.; Winthrop, K.L.; Beukelman, T.; Bridges, S.L., Jr; Chatham, W.W.; Paulus, H.E.; Suarez-Almazor, M.; Bombardier, C.; Dougados, M.; Khanna, D.; King, C.M.; Leong, A.L.; Matteson, E.L.; Schousboe, J.T.; Moynihan, E.; Kolba, K.S.; Jain, A.; Volkmann, E.R.; Agrawal, H.; Bae, S.; Mudano, A.S.; Patkar, N.M.; Saag, K.G. 2012 update of the 2008 American College of Rheumatology recommendations for the use of disease-modifying antirheumatic drugs and biologic agents in the treatment of rheumatoid arthritis. Arthritis Care Res. (Hoboken), 2012, 64(5), 625-639.

[http://dx.doi.org/10.1002/acr.21641] [PMID: 22473917]

[59] Smolen, J.S.; Landewé, R.; Breedveld, F.C.; Dougados, M.; Emery, P.; Gaujoux-Viala, C.; Gorter, S.; Knevel, R.; Nam, J.; Schoels, M.; Aletaha, D.; Buch, M.; Gossec, L.; Huizinga, T.; Bijlsma, J.W.; Burmester, G.; Combe, B.; Cutolo, M.; Gabay, C.; Gomez-Reino, J.; Kouloumas, M.; Kvien, T.K.; Martin-Mola, E.; McInnes, I.; Pavelka, K.; van Riel, P.; Scholte, M.; Scott, D.L.; Sokka, T.; Valesini, G.; van Vollenhoven, R.; Winthrop, K.L.; Wong, J.; Zink, A.; van der Heijde, D. EULAR recommendations for the management of rheumatoid arthritis with synthetic and biological diseasemodifying antirheumatic drugs. Ann. Rheum. Dis., 2010, 69(6), 964-975.

[http://dx.doi.org/10.1136/ard.2009.126532] [PMID: 20444750]

[60] Myers, L.K.; Rosloniec, E.F.; Cremer, M.A.; Kang, A.H. Collagen-induced arthritis, an animal model of autoimmunity. Life Sci., 1997, 61(19), 1861-1878.

[http://dx.doi.org/10.1016/S0024-3205(97)00480-3] [PMID: 9364191]

[61] Kannan, K.; Ortmann, R.A.; Kimpel, D. Animal models of rheumatoid arthritis and their relevance to human disease. Pathophysiology, 2005, 12(3), 167-181.

[http://dx.doi.org/10.1016/j.pathophys.2005.07.011] [PMID: 16171986]

[62] Trentham, D.E.; Townes, A.S.; Kang, A.H. Autoimmunity to type II collagen an experimental model of arthritis. J. Exp. Med., 1977, 146(3), 857-868.

[http://dx.doi.org/10.1084/jem.146.3.857] [PMID: 894190]

[63] Schurgers, E.; Billiau, A.; Matthys, P. Collagen-induced arthritis as an animal model for rheumatoid arthritis: focus on interferon- $\gamma$. J. Interferon Cytokine Res., 2011, 31(12), 917-926.

[http://dx.doi.org/10.1089/jir.2011.0056] [PMID: 21905879]

[64] Lindqvist, A-K.; Bockermann, R.; Johansson, Å.C.; Nandakumar, K.S.; Johannesson, M.; Holmdahl, R. Mouse models for rheumatoid arthritis. Trends Genet., 2002, 18(6), S7-S13.

[http://dx.doi.org/10.1016/S0168-9525(02)02684-7]

[65] Cho, Y.G.; Cho, M.L.; Min, S.Y.; Kim, H.Y. Type II collagen autoimmunity in a mouse model of human rheumatoid arthritis. Autoimmun. Rev., 2007, 7(1), 65-70. [http://dx.doi.org/10.1016/j.autrev.2007.08.001] [PMID: 17967728]

[66] Hegen, M.; Keith, J.C., Jr; Collins, M.; Nickerson-Nutter, C.L. Utility of animal models for identification of potential therapeutics for rheumatoid arthritis. Ann. Rheum. Dis., 2008, 67(11), 1505-1515.

[http://dx.doi.org/10.1136/ard.2007.076430]

[PMID: 18055474]

[67] Holmdahl, R.; Bockermann, R.; Bäcklund, J.; Yamada, H. The molecular pathogenesis of collagen-induced arthritis in mice--a model for rheumatoid arthritis. Ageing Res. Rev., 2002, l(1), 135-147.

[http://dx.doi.org/10.1016/S0047-6374(01)00371-2] [PMID: 12039453]

[68] Wooley, P.H. The usefulness and the limitations of animal models in identifying targets for therapy in arthritis. Best Pract. Res. Clin. Rheumatol., 2004, 18(1), 47-58. [http://dx.doi.org/10.1016/j.berh.2003.09.007] 15123037]
[PMID: 